\title{
3. THE FIELDS OF ARTS THE GENERAL EDUCATION SYSTEM THE REPUBLIC OF MOLDOVA
}

Marina Morari ${ }^{16}$

\begin{abstract}
The general education system identifies two approaches for encompassing arts: through the curricular field and through the extracurricular and extra-scholastic aesthetic education. The fields of arts are assigning a sector, an area of activity, a branch or a compartment. In the general education system, the fields of art have been differently formed. As a school subject, art is being studied through literature, music and fine arts. Some of them are not included in the educational plan (theatre, choreography). The statute of arts (literature, music, fine arts) in the educational system is outlined from two perspectives: art as a school subject and art as an artistic activity. The area of art shall not be reduced to a school subject or a type of arts. The artistic education in the educational system corresponds to the aesthetic education compartment and it happens in the extracurricular and extrascholastic educational framework. According to the classic, traditional theory, the aesthetic education often is reduced to the level of artistic education. An efficient perspective in capitalizing the fields of art through education may be the extension of the artistic education borders outside the aesthetic values, by extra-aesthetic values - behavioral, moral, spiritual, social etc.
\end{abstract}

Key words: the general education system, the fields of art, artistic education, aesthetic education, the curricular field Arts

\section{Introduction}

From ancient times till present, arts are included in education. The antic phrase „man developed armonis" is still not losing its topicality. „Art is the essence of the being", according to the French philosopher of Bessarabian origin, Ștefan Lupașcu [Apud: 15, p.18]. The modern reality confirms that by excluding art from a child's life, is like excluding education from his life. Educating the person is the common purpose of pedagogics and arts. In the human society, art operates under different aspects: (a) practical-utilitarian (accompanying different daily activities related to labour, holidays, cult, ritual); (b) general-aesthetic (embellishing life); (c) artistic (artistic creations and artistic performances as concerts, festivals, vernisages, plays, exhibitions, etc.) [6, p. 37].

In C. Cucos's opinion [4, p.22], the new performances of the social, cultural and technological praxis activate new arguments for grounding the educational efforts through arts, on the following grounds: 1. Axiological, 2. Cultural, 3. Related to self-realization and self-affirmation of the person, 4. Sympathetic, sharing the experiences and mutual acceptance, 5 . The grounds of the identity structure and formation, 6 . The grounds of the positive use of the time, 7 . The grounds of the projection and transparency of the individual and humanity, 8. The grounds of the creativity potential, 9. The grounds of modelling the existence according to the artistic exemplarity. These grounds represent arguments for the support of the need of a coherent and responsible effort,

\footnotetext{
${ }^{16}$ Associate Professor PhD, „Alecu Russo” State University from Bălţi, Republic of Moldavia, email: mmmorari@gmail.com
} 
inspired by pedagogical foundation of the artistic education realized within the school.

In I.Gagim's opinion, understanding the relationship „man - art” in the educational act depends on its functions [6, p.22-23]: gnoseological, axiological, hedonistic, suggestive, illuminist, communicative, heuristic, catharsis, esthetical, educative. All these functions could be summed up to four forms of attraction for art $[10, \mathrm{p} .6]: 1$. In its largest meaning, art may be entertaining; 2 . Art can attract by its power of reflect reality, natural world or that of the thoughts and actions of the humans; 3 . Art provokes aesthetic attraction, through which the beauty is perceived from art and life; 4. Art offers a hierarchy of the psychological, moral and spiritual values.

As N. Hartmann states [8], the world created through the work of art is a world existing through its value, but it exists for a living spirit, interfering twice: (1) in the modelling of the artistic matter and its impregnation with the spiritual content, (2) in the receipt and recognition of what the creating spirit incorporated in the work of art. From this perspective, the values of education through the intermediary of all fields of art, if selected carefully, can become future life values of student's personality. Artistic cognition, specific to all types of art, are realized by means of emotional sufferings-imagination-thinkingartistic creation, being oriented towards self-knowledge and towards the creation of the inner human universe [13, p. 10].

How do arts configure in the general education system and which are the perspectives of their practical use in education? We will answer to these questions on the basis of the general education system from the Republic of Moldova. The word "field" comes from the French word domaine, the latin dominum. As regards arts, this term means a sector, a sphere of activity, area, unit, sphere. Therefore, the field of an art is not limited to a school subject or a certain type of art.

\section{The status of arts in the education system}

According to the classic, traditional concept, the aesthetic education is often limited to the level of artistic education or the perception of artistic education supposes only one "pattern of aesthetic education, exemplary through its capacities of modelling sensitivity, rationality and human creativity" $[13, \mathrm{p}$. 110]. ,Aesthetic education represents the activity of formation-development of human personality, designed and realized by means of reception, assessment and creation of values of the existent beautiful in nature, society and art" [3, p.109]. For transforming art in an "ideal of all human activities", as emphasizes T. Vianu [17, p.100], can be extended the limits of the range of artistic education beyond the aesthetic values, towards extra-aesthetic-behavioural, moral, spiritual, social values, etc. Thus, art can become a method of educating general human values, national values, family values, etc.

The notion of artistic education is interpreted as a continuous individual process of spiritual self-improvement of personality by means of multiple forms of contact with art [5, p.5]. „Artistic education can awaken hidden possibilities and skills in children. It is a way of discovering personal secrecies of the human 
being. Through art must be cultivated the joy of creation and of artistic experience" [4, p.21]. Artistic education, as an essential factor of aesthetic education, is realized by perceiving the beautiful, by means of different arts: literature, music, drawing, theatre, choreography, etc.

The status of arts in the education system is configured from two perspectives: 1 . Art as a school subject; 2 . Art as an artistic activity. As result, art as a school subject is studied through the intermediary of literature, music and fine arts (according to the Curriculum approved by the Ministry of Education No.312 as of May 14, 2015). The artistic activity in the education system corresponds to the unit of aesthetic education and is conducted in the extracurricular and extra-scholastic educational framework.

The artistic-aesthetic education in general education institutions from the Republic of Moldova is promoted by the curricula of such subjects as Romanian Language and Literature, Music Education, Artistic-Visual Education and extracurricular cultural-artistic activities from each educational institution. According to the above stated findings, it results that the fields of arts are configured differently in the general education system. This fact is confirmed in the Curriculum for primary, junior high-school and lyceum education. We outline that the Curriculum is an essential regulatory component of the National Curriculum, ensures the necessary educational framework for the formation of personality with a spirit of initiative, able to self-develop, showing independence in opinions and actions, is responsible, open for intercultural dialogue in the context of national and international values $[16, p .5]$. The Curriculum provides to each student opportunities for the formation and development of a system of sufficient skills for acceding to the following education levels. The Curriculum is approved by the order of the minister and is mandatory for all primary, junior high-school and lyceum educational institutions. Based on the analysis of Curriculum for the primary, junior high-school and lyceum education (for the academic year 2015-2016), it had been found that:

- The field of Literature is represented through the school subject Romanian Language and Literature in the $1^{\text {st }}-12^{\text {th }}$ forms, World Literature - in the $10^{\text {th }}-$ $12^{\text {th }}$ forms, only for the students from the humanities major and the activity of extra-scholastic educational-artistic clubs;

- The Field of Music is studied through the subject Music Education in the $1^{\text {st }}$ $8^{\text {th }}$ forms, the activity of glee clubs, chorus etc.;

- The Field of Fine Arts is studied through the subject Fine Arts in the $1^{\text {st }}-7^{\text {th }}$ forms and indirectly through the subject Technological Education.

Thus, we found that the other arts: theatre, choreography, etc. are exploited in the educational system only within extracurricular activities and their weight in education differs a lot from one educational institution to another.

Item 1.4. Organisation of extra-scholastic activities from the Curriculum, recommends to the Boards of Directors of educational institutions to approve the distribution of lessons for this component [16, p.8]. In item 1.5. Optional subjects from the Curriculum, provide to each student the possibility of choosing various optional subjects. Optional subjects represent the flexible component of 
the Curriculum, intended to contribute first of all to the development of certain transversal skills [idem, p.9].

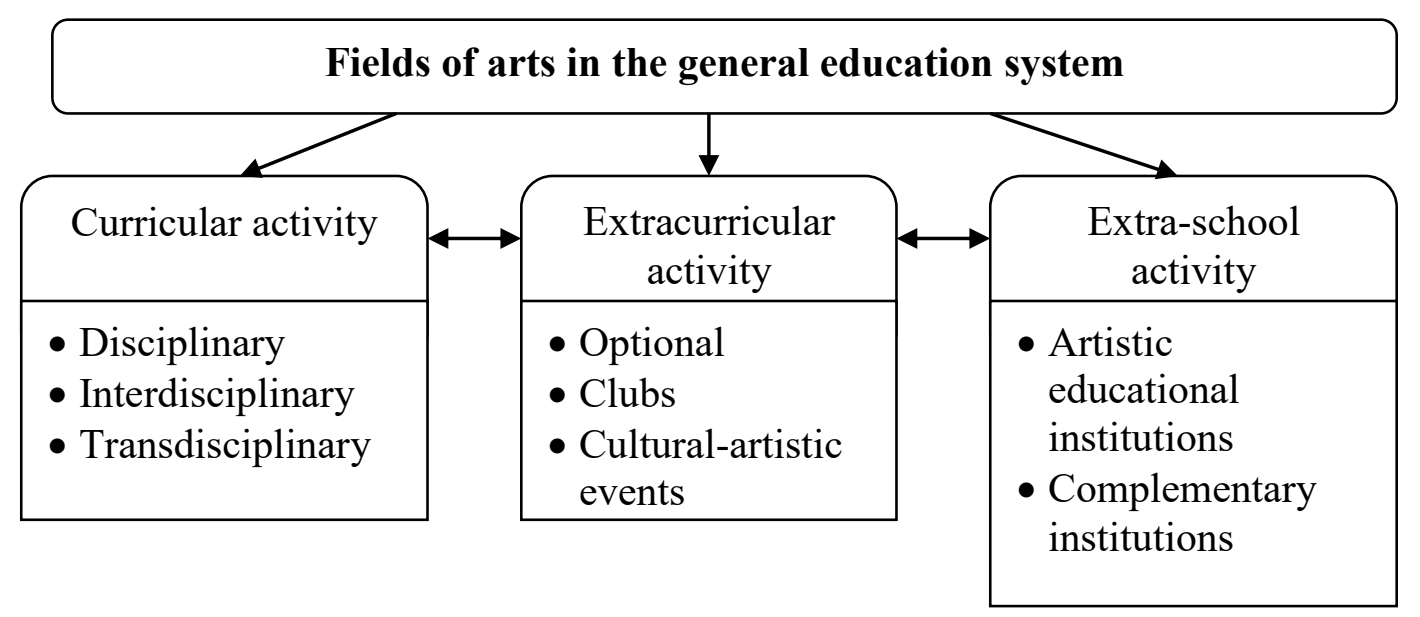

Figure 1. How the fields of arts articulate in the general education system.

In practice, the status and delivery of art in education are less obvious. We identify two approaches for encompassing arts in the general education system, according to the national regulatory document: (1) through the curricular field (the curricular field of Arts with two separate subjects - music education, fine arts and the curricular field of Language and Communication with the subjects Romanian Language and Literature, World Literature); (2) through extracurricular and extra-scholastic aesthetic education - through the intermediary of optional classes and extra-scholastic clubs. We emphasize the fact that the Romanian Literature is a part of the study of the "native" language and, even if it is not included in the curricular field of Arts, it forms literary-artistic competencies.

Among the didactic staff, arts have a lower status than the other school subjects. This is due to the relative lack of attention paid to the assessment and monitoring of standards in teaching arts. Students' progress in artistic education in primary classes is inhibited for a series of reasons: Music Education and Fine Arts are taught predominantly by teachers of primary classes (non-specialists in the field); the lack of a specialist in an educational institution with a small number of classes or an incomplete didactic load (less than 9 hours per week); the lack of specialized classrooms (fitted with music instruments, music centre, digital equipment, etc.); the lack of competent methodical assistance from the part of district education divisions; delegation of responsibility for the subjects of the curricular field of Arts at district education divisions to non-specialists, etc.

After the discussions with the didactic staff teaching subjects from the curricular field of Arts in junior high-school classes, had been identified the following problems in the organization of the educational-artistic process: the low level of the degree of initiation of students of primary classes in curricular contents, the lack of a communication culture and of an elementary artistic expression of students at the end of the $4^{\text {th }}$ form, difficulties in the 
realization of curriculum at subjects from the curricular field of Arts in the $5^{\text {th }}$ form, poor attention from the part of the administrations of educational institutions for the monitoring of the quality of teaching subjects from the curricular field of Arts, etc.

\section{The concept of school subjects in the field of arts: historical evolution}

The real education reform from the Republic of Moldova anticipated the declaration of independence and provided the necessary conceptual framework for complex changes in the field. In 1989 had been published the Concept of secondary education of general culture in the Moldovan SSR and only in 1994 it had been approved as an official state document, with the name: Concept of education development in the Republic of Moldova, after the revision within the Commission for culture, science, education and mass-media of the parliament. As V. Pâslaru states, "education reconceptualised, providing not only a vision of its own field, but also a new perception of the method in which is possible and necessary the cultural-spiritual and social-political life of people from the territory which later became the Republic of Moldova" [12, p.11].

In 1995-2005, the Institute of Education Sciences (IES) drafted the National Education Program of the Republic of Moldova, representing the most important strategies and objectives of all the fields participating in the training and education process. The Institute had to draft also the conceptions of all school subjects stipulated in the curriculum, fact which had been accomplished only partially.

\subsection{Literary-artistic education}

In the $80 \mathrm{~s}$ ( $20^{\text {th }}$ century) had been developed and founded the theory of literary-artistic education by Vl. Pâslaru [15], based on the concept of the literature teaching method of C.Parfene and the reading theory of P.Cornea, the philosophy of Im. Kant, G.F.Hegel, W. Von Humboldt, Șt. Lupașcu, L. Blaga and C. Noica. The main goal of literary-artistic education defined itself by the formation of the educated reader of literature in accordance with the general educational ideal/goal, the principles of literature and art, the principles of literary and artistic education [idem, p.20]. The point of view of professor Vl. Pâslaru is relevant, which particularizes the definition of this goal: „The literature reader is subject-object in permanent changing and is aspiring towards the value of self-fullness, the image of an axiology designed as possible by the tendency of a close reproduction of the sources of artistic cognition; the second subject creator of the literary work". [ibidem, p.21]

The conception of school subject Romanian Language and Literature had been drafted on the basis of the theory of literary-artistic education and, as result, there had been conceived the first theoretical curriculum pattern for Romanian Language and Literature. Indeed, the theoretical basis of literaryartistic education represents "doors" for all the field of artistic education: musical, choreographic, theatrical, artistic-visual, etc. The system of artisticvisual principles, drafted by the scholar Vl.Pâslaru, discloses the origin and essence of literature and art for education sciences. For artistic education, the following two principles are constituent [15, p.106]: „1. Literature and art are 
marked by the overall spirit of humanitas, the human being is attitudinally reported to the field of hypersensitivity, he creates it and knows it better, thus, increasing his own value: the human being creates/exploits the essence in the artistic creation (production-reception of the work of art), there being defined such an objective as the unique subjective being. 2. To consider literature and art fields of the hypersensitivity, in complex relation with the sensitively-perceived world: the reality of the work of art is defined under the sign of creation; art produces its own reality in the necessary manner and with an end point determined by the human being".

\subsection{Music education}

Along with the foundation of the literary-artistic education, there had been also drafted the Conception of music education in pre-university education, the unique conception of artistic education based on a field (examined and approved at the meeting of the College of the Ministry of Education as of April 20, 1995). This document had been drafted under the aegis of the laboratory of artistic education of the Institute of pedagogical and psychological sciences (currently: the Institute of Education Sciences from Chisinau). For defining more precisely and more exactly the aim of education through "the art of sound", it was necessary to specify the name of the school subject which oscillated along the time: "Singing", "Singing and Music", "Music". The name of the subject determines the dominant activity of the lesson. The name "Music Education" is more complex and is guided by a dominant orientation - "Educating the human being and not the musician" [2, p.6]. The failure to understand the meaning of dominant orientation is caused by the confusion of the two types of music education: 1. Special music education, music major, professional, aiming at cultivating singers, composers, musicologists; 2 . General music education, of masses, the mission of which is "to initiate simple people in the art of music, to awaken their interest in music, to make them understand it, to acquire it as an element of general culture" [6, p.38]. The common element of both forms of education is music, but each of them is realised in its own way, depending on the expected outcome.

In the Conception of music education (1995), the notion „music education” is interpreted as a continuous individual process of spiritual self-improvement of personality by means of multiple forms of contact with art $[2, \mathrm{p} .6]$. Thus, teaching-learning Music Education must be performed by means of several forms of musical initiation: audition, interpretation, musical pieces, analysischaracterization and appreciation of music. We found that primary one is the spiritual formation of student's personality through the exploitation of his musical potential and edification of his own virtues.

The contents of this conception became a foundation for the development of a new content of music education, which had been developed in the experimental programs edited in 1990, 1992, in phono-chrestomathies, in the Curriculum of Music Education (2000 edition), in the modernized Curriculum of Music Education (2010), in school books and professors' guidebooks, the efficiency standards of learning musical art, the assessment reference of 
competencies specific to music education, etc. Music education claims the status of school subject in the researches of the academician Dm. Kabalevski (the 80s of the $20^{\text {th }}$ century) and had been psychopedagogically and musicologically founded by professor Ion Gagim [7].

The fundamental contradictions of modern music education, through which I.Gagim is marking three problems in the praxiology of the field of music education, these are relevant in the educational-artistic practice for all the fields of artistic education [idem]:

- Between the principles of general didactics, determined by the objectivesubjective nature of the object of scientific cognition (physical existence), and subjective-objective nature (essence) of music (metaphysical existence);

- Between the dichotomy of the aim of music education (its double-unitary character) and the unilateral methodological instrumentation of the process of its realisation;

- Between the advanced modern level of sciences about music and the obsolete level of the theoretical framework of teaching-learning music in contemporary schools.

The values of music education in pre-university education, from the modernized curricula perspective, integrate [11, p.9-10]: the musical experience as a quintessence of the musical act; musical culture as an outcome of music education; the principle of thematism on the path of curricular realisation; the lesson of music education as a form of musical-pedagogical activity (creation), conceived on the basis of the principles of artistic dramaturgy; the system of musical-didactic activities of students as a product derived from the four forms of music activity: creation-interpretation-audition-analysis; musical culture encompassing the role, functions and outcomes of culture in general, during which the student, getting to know/exploiting the world, is getting to know/exploiting himself as a spiritual being.

\subsection{Artistic-visual education}

A distinctive feature of the curriculum of artistic-visual education, as noted in the Methodological Guide of Artistic Education [5, p.28], „consists in teaching visual arts as an aesthetic-educational process and connecting the pedagogical conditions to the principles of art, observing the peculiarities of the infantile visual creation”. In the curriculum for 2000, it is opted for „overcoming the reproductive aspect of the artistic-visual act and the formation of a creative personality with production/reception skills of visual values, able to appreciate the values of national and world visual culture and to detect the kitsch" [5]. One of the special features of the curriculum of artistic-visual education (2000 edition) is the study of elements of visual language, of principles of organization of visual compositions in a scientific system, which were directly conditional on the method of expressing the curricula contents. Even if the problem of compelling the student to accomplish difficult tasks for representing the visual image in accordance with the requirements of the academic training, had been solved, the experience of artistic reception, creation and communication in the 
field of visual arts had been dominate by the technological part of visual education (visual training).

Integration of the act of creation in the educational process by acquiring the principles of representation of visual images had been the main idea of the curriculum. The didactic staff had been instructed to follow the main idea in the organization and performance of artistic-visual education, which consists in the fact that 'the artistic-visual image is the result of students' act of creation and also a working method" [5, p.28]. Therefore, the informative part dominated the formative part of the process of artistic-visual education. The creation and understanding of the artistic-visual image, created by the cognition of: 1 . visual language, 2. principles of organization of composition and techniques from the perspective of the history of visual arts. We notice a decrease of the importance of the impact of the works of art on student's personality, on the vision, values and attitudes of students, not only for art, but for the life itself. The study of visual arts in general education institutions had been more of a purpose than a means of education. Indeed, the formative aspect of the artistic-visual education is limited to the formation of certain technological capacities and skills in the field of creation/reception of a piece of art and less, or not at all, to the formation of the artistic-visual culture as a component part of the entire spiritual culture of students. The subject of Artistic-visual education reformulated into Visual education. The abundant use of the term "training" in the explanation of the conception of modernized curriculum denotes authors' increased concern for the study of visual arts at technological level.

Human personality, nature, science, art - are the factors which contribute to the edification of student's values and confers integrity to the process and outcomes of the educational-artistic process. We support the idea of L.Bârlogeanu, according to which the work of art from any field institutes a "pattern-world", institutes a value and thus, is influencing the common method of reporting to the world, by reporting to the value [1, p.74].

\section{Conclusions}

The theory of artistic-aesthetic education [13, p.9-15] in the Republic of Moldova had been materialized and developed in the researches of certain followers of the Moscow school, who, at their turn, instituted schools of artisticaesthetic education in particular fields, such as:

- The field of literary-artistic education with the followers: L.Botezatu, V.Pâslaru, M.Hadîrcă, A.Fekete, S.Posternac, M.Marin, C.Taiss, R.Burdujan,L.Martîniuc, L.Frunză, S.Golubițchi, N.Baraliuc, A.Șchiopu;

- The field of music education with the followers: S.Croitoru, A.Popov, E.Coroi, I.Gagim, A.Borș, A.Stîngă, M.Tetelea, V.Babii, M.Vacarciuc, M.Morari, T.Bularga, L.Granețkaia, M.Cosumov, V.Crișciuc and others;

- The field of artistic-visual education with the followers: O.Arbuz-Spatari, C.Gheorghiță, L.Vozian, A. Blaja-Vitkovski, Gh. Popa, etc.

In the opinion of professor Vlad Pâslaru, ,the artistic-aesthetic education is congenital and distinguishing for the human being, it is identified with the artistic-aesthetic cognition, which was stably built in a field/type of education as 
a branch of education sciences, following specific goals and objectives, through the exploitation of certain special educational contents, executed by means of efferent methodologies based on its own system of principles. Ignoring the artistic-aesthetic education will lead to the degradation of the human being" [13, p. 14].

In conclusion, we should note that the fields of arts in the general education system had been subjected during the last three decades to certain essential changes, comprising the teleological, contentwise and technological components. The modern artistic education is nothing but the education integrating the being of the educated person, an education which is exploiting/cultivating the aggregate of the human being through the intermediary of all the fields of art. To educate through the fields of arts in the general education system means to facilitate an experience of values, which should be progressively integrated in students' personality. From such a perspective, we can outline the following perspectives:

- What we do in education through arts must follow the goal of updating the potentials of the being (arts open the doors to what is happening in our inner world and in the around us).

- The reorganisation of the curricular contents and technologies at the subjects of the curricular field of Arts must be reported to a common end point - the artistic culture of students as a component part of the entire spiritual culture.

- The relation between arts and life must be conditional on all the components of the curriculum: principles of organization of the artistic education, artistic competencies, contents and technologies of the educational process;

- The names of school subjects from the field of arts must correspond to the conception of artistic-aesthetic education of students from the general educational institutions (must not be contradictory);

- The interdisciplinary integration of artistic fields must be explored in the education of students from the $9^{\text {th }}-12^{\text {th }}$ forms, by virtue of the exclusion from the curriculum of the subjects from the curricular field of arts.

- The extension of the boundaries of the artistic education beyond the aesthetic values, towards extra-aesthetic - behavioural, moral, spiritual, social values, etc.

\section{References}

1. Bârlogeanu, L. (2001). Psihopedagogia artei. Educația estetică. Iași: Polirom

2. Chiriac, T., Mamot, E., Rusnac, C. (1995). Concepția Educației muzicale în învățămîntul preuniversitar. Chișinău: Ministerul Învățămîntului

3. Cristea, S. (2000). Dicționar de pedagogie. Chișinău-București: Litera Internaţional

4. Cucoș, C. (2014). Educație estetică. Iași: Polirom

5. Gagim, I. (2004). Fundamente psihopedagogice și muzicologice ale educației muzicale. [Referat șt. al tezei de doctor habilitat în baza lucrărilor publicate în pedagogie]. Chișinău: IȘE 
6. Gagim, I. (2006). Știința și arta educației muzicale. Chișinău: ARC

7. Guţu, V., Coroi, E. (coord.). (2000). Educație artistică. Ghid metodologic: Dezvoltarea și implementarea curriculumului în învățămîntul gimnazial.Chișinău: Litera, Ministerul Educației și Științei al RM

8. Hartmann, N.(1984). Estetica. București: Univers enciclopedic

9. Lihaciov, B.T. (1975). Principiile și sarcinile de bază ale educației estetice. In основы эстетического воспитания. Москва

10. Ministerul Educaţiei al RM. (2015). Planul-Cadru pentru învăţămîntul primar, gimnazial şi liceal pentru anul de studii 2015-2016. Chişinău

11. Morari, M. (2007). Teoria elementară a muzicii. [Curs universitar]. Bălți: Presa universitară bălțeană

12. Morari, M. (2011). Educația muzicală: Ghid de implementare a curriculumului modernizat pentru învățămîntul primar/gimnazial. Chișinău: Lyceum

13. Pâslaru, V. (2002). Educația artistic-estetică: reconstituirea esenței. In Educația prin artă în învățămîntul preuniversitar [Materialele Conferinței Republicane, 8-9 decembrie 2001, Comisia Națională a RM pentru UNESCO, Ministerul Învăţămîntului din RM]. Chișinău: Grafema Libris

14. Pâslaru, V. (2014). Cunoașterea umană și educația artistic-estetică. Didactica Pro. Revistă de teorie și practică educațională a Centrului Educațional Pro Didactica, 1(83), 9-15

15. Pâslaru, V. (2015). The Theory of Artistic-Aesthetic Education versus Didactics of Arts. In Railean, E., Walker G., Elçi, A., \& Jackson, L. (Eds.), Handbook of Research on Applied Learning Theory and Design in Modern Education (65-92). Hershey, PA: IGI Global

16. Pâslaru, Vl. (2001). Introducere în teoria educației literar-artistice. Chișinău: Museum

17. Vianu, T. (2010). Estetica. București: Orizonturi 